University of South Carolina

Scholar Commons

$1-17-2003$

\title{
Abundance of Amino Sugars and Peptidoglycan in Marine Particulate and Dissolved Organic Matter
}

\author{
Ronald Benner \\ University of South Carolina - Columbia, benner@mailbox.sc.edu \\ Karl Kaiser \\ University of South Carolina - Columbia, karl@biol.sc.edu
}

Follow this and additional works at: https://scholarcommons.sc.edu/biol_facpub

Part of the Marine Biology Commons

\section{Publication Info}

Published in Limnology and Oceanography, Volume 48, Issue 1, 2003, pages 118-128.

(c) Limnology and Oceanography 2003, Association for the Sciences of Limnology and Oceanography.

This Article is brought to you by the Biological Sciences, Department of at Scholar Commons. It has been accepted for inclusion in Faculty Publications by an authorized administrator of Scholar Commons. For more information, please contact digres@mailbox.sc.edu. 


\title{
Abundance of amino sugars and peptidoglycan in marine particulate and dissolved organic matter
}

\section{Ronald Benner ${ }^{1}$ and Karl Kaiser}

Department of Biological Sciences and Marine Science Program, University of South Carolina, Columbia, South Carolina 29208

\begin{abstract}
Several recent studies indicated that amino sugars were likely to be major components of marine carbon and nitrogen cycles, but there has been insufficient data to investigate this hypothesis. In the present study, hydrolyzable amino sugars were measured in a variety of marine organisms and particulate organic matter (POM) and in ultrafiltered dissolved organic matter (UDOM) from various ocean basins and depths. Glucosamine (GlcN) and galactosamine (GalN) were abundant and common to all samples. Concentrations of these two amino sugars were similar to their neutral sugar counterparts, glucose and galactose, and in surface water they accounted for up to $\sim 1.5 \%$ of $\mathrm{C}$ and $\mathrm{N}$ in POM and $2.5 \%$ of $\mathrm{C}$ and $7.1 \%$ of $\mathrm{N}$ in UDOM. Chitin, a polymer of glucosamine, is produced by many marine organisms, but based on the low GlcN: GalN ratios (1.0-2.5) in POM and UDOM, it does not appear to be a primary source of glucosamine in these samples. Muramic acid, an amino sugar found only in the bacterial cell wall polymer peptidoglycan, was relatively abundant in POM, indicating that bacterial detritus is a principal component of submicron particles in seawater. Muramic acid was measured in all UDOM samples, but its concentrations were low $\left(<1 \mathrm{nmol} \mathrm{L} \mathrm{L}^{-1}\right)$, indicating that intact fragments of peptidoglycan were a relatively minor component of UDOM. The abundance of GlcN and GalN and their similar concentrations in POM and UDOM provide novel information suggesting a major prokaryotic source.
\end{abstract}

Amino sugars are often considered to be abundant components of marine organic matter, yet there are surprisingly few measurements of amino sugars in the marine environment. Chitin, a structural polymer of the amino sugar $N$ acetyl-glucosamine, is produced by a large variety of marine organisms (Muzzarelli 1977), and the production of chitin in the oceans is undoubtedly quite large. Kirchman and White (1999) estimated that about $10 \%$ of marine bacterial production could be supported by chitin. In addition to chitin and its derivatives, amino sugars are found in other polysaccharides, glycoproteins, and glycolipids that are common to many organisms (Sharon 1965). Amino sugars are important structural components of prokaryotic cell walls, where they occur in peptidoglycan, lipopolysaccharides, and pseudopeptidoglycan (Brock et al. 1994). Several studies provide measurements of amino sugars in marine particles and sediments (Ittekot et al. 1984; Müller et al. 1986; Liebezeit 1993; Dauwe and Middelburg 1998), but existing in-

\footnotetext{
${ }^{1}$ Corresponding author (benner@ @biol.sc.edu).
}

\section{Acknowledgments}

We dedicate this paper to the memory of John I. Hedges. John provided valuable comments on an earlier draft of this manuscript and many hours of stimulating discussion on the chemical composition of DOM. We thank Rumi Fukuda for providing samples of natural populations of marine bacteria collected from seawater, W. Whitman for providing cultures of methanogens, and José Bersano for assistance with the collection and sorting of copepods. We thank scientists and crew aboard the USS Hawkbill and RV Weatherbird and Vickers for assistance with sampling, David Kirchman, the biogeochemistry group at the University of South Carolina, and two anonymous reviewers for comments on an earlier draft of this manuscript. This research was funded by National Science Foundation grants OCE-0080782 and OPP-9996438. formation is insufficient to provide more than a glimpse of the significance of amino sugars in the ocean.

It is now well recognized that carbohydrates are among the most abundant and reactive components of the marine $\mathrm{C}$ cycle (Romankevich 1984; Benner et al. 1992; Pakulski and Benner 1994). The development of sensitive methods for the measurement of neutral sugars in seawater has greatly advanced understanding of the abundance, distribution, and cycling of these common carbohydrates in the ocean (Mopper et al. 1995; Borch and Kirchman 1997; Skoog and Benner 1997). Similar methods were recently developed for the measurement of amino sugars in seawater (Kaiser and Benner 2000), and this report provides a first look at the biogeochemistry of amino sugars in particulate and dissolved organic matter. Amino sugars are unusual carbohydrates in that they contain nitrogen. Most $\mathrm{N}$ in marine dissolved organic matter (DOM) resides in amide functional groups, which are common to combined amino acids and acetylated amino sugars (McCarthy et al. 1997). Hydrolyzable amino acids account for $<15 \%$ of dissolved organic nitrogen in seawater, suggesting that amino sugars could be important in the marine $\mathrm{N}$ cycle (McCarthy et al. 1997).

Chemical characterization of a variety of biomolecules in marine organic matter indicates that bacteria are an important source of marine DOM (Tanoue et al. 1995; Boon et al. 1998; McCarthy et al. 1998). Most of the characterized biomolecules are commonly or uniquely found in bacterial cell walls. Peptidoglycan is the dominant cell wall polymer found in bacteria, and existing data suggest this bacterial polymer could be a major component of refractory DOM in the ocean (Boon et al. 1998; McCarthy et al. 1998). Amino sugars form the glycan "backbone" of peptidoglycan, and the characterization of specific amino sugars in marine particulate and dissolved organic matter provides new insights 
Table 1. Recoveries of amino sugars from purified polymers.

\begin{tabular}{llll}
\hline \hline \multicolumn{1}{c}{ Polymer } & \multicolumn{1}{c}{ Source } & Amino sugar & Recovery $(\%)$ \\
\hline Chitin & Sigma C-8908 & Glucosamine & 78 \\
Chondroitin sulfate A & Sigma C-8529 & Galactosamine & 78 \\
Peptidoglycan & Wako 162-18101 & Glucosamine & 74 \\
(from M. luteus) & & Muramic acid & 63 \\
\hline
\end{tabular}

about the occurrence and refractory nature of peptidoglycan in marine organic matter.

\section{Materials and methods}

Sampling - Seawater samples were collected from the Pacific (February-March 1992, RV John Vickers), Atlantic (May 1992, RV Weatherbird), and Arctic Oceans (AugustSeptember 1998, USS Hawkbill) using a high-volume pump (Pacific and Atlantic surface samples) or Niskin bottles. Samples collected in the Pacific and Atlantic were processed aboard ship immediately following collection. Samples collected from the Arctic were preserved with mercuric chloride $\left(0.15 \mathrm{mmol} \mathrm{L}^{-1}\right)$ and processed in the home laboratory within 3 months of collection. Pacific samples were passed through a Nitex sieve (60 $\mu \mathrm{m}$ pore size) and processed by tangential-flow filtration to recover two size classes of marine organic matter: particulate organic matter (POM; 0.1$60 \mu \mathrm{m}$ pore size) and ultrafiltered dissolved organic matter (UDOM; 1-100 nm). Atlantic and Arctic samples were passed through Nuclepore cartridge filters $(0.2 \mu \mathrm{m}$ pore size), and the UDOM size fraction (1-200 nm) was recovered using tangential-flow ultrafiltration. Concentrates from tangential-flow filtration were diafiltered with Milli-Q water to remove sea salts, and the desalted concentrates were dried under vacuum. Sample handling and ultrafiltration procedures followed the methods of Benner et al. (1997).

Cultures-Cultures and natural populations of a wide diversity of organisms were analyzed to determine primary sources and yields of amino sugars. Axenic cultures of marine algae (Heterocapsa niei CCMP 447, Nannochloris sp. CCMP 518, Emiliania huxleyi CCMP 373, Thalassiosira oceanica CCMP 1005) and the marine bacterium Synechococcus sp. CCMP 1334 were obtained from the culture collection at Bigelow. The marine bacterium Synechococcus bacillaris CCMP 1333 also was obtained from Bigelow and cultured as described in Biddanda and Benner (1997). Freeze-dried cultures of two soil bacteria, Bacillus subtilis ATCC 6633 and Pseudomonas fluorescens ATCC 13430, were obtained from Sigma Chemical. A wild population of Trichodesmium sp. was collected in August 1995 from surface waters of the Gulf of Mexico (Biddanda 1995). Natural populations of marine bacteria (prokaryotes) were collected from coastal and oceanic waters by size-selective filtration methods (Fukuda et al. 1998). Natural populations of the copepod Acartia tonsa were collected from coastal waters of the Gulf of Mexico and sorted (male and female) using a dissecting microscope. Two cultures of methanogenic Archaea, Methanobrevibacter smithii and Methanococcus mar- ipaludis, were obtained from W. Whitman at the University of Georgia.

Measurements-Concentrations of dissolved organic carbon (DOC) were determined using a high-temperature combustion method and a Shimadzu TOC 5000 analyzer (Benner and Strom 1993). The organic carbon and nitrogen content of dried POM and UDOM samples were measured after vapor phase acidification using a Carlo Erba $1108 \mathrm{CHN}$ analyzer.

Amino sugars (glucosamine, galactosamine, mannosamine, muramic acid) were separated and measured using highperformance anion exchange chromatography (HPAEC) with pulsed amperometric detection (PAD). Sample preparation and chromatography conditions followed the procedures of Kaiser and Benner (2000) and are briefly presented here. A Dionex 500 ion chromatography system with a CarboPac PA1 column and PAD detector were used for all analyses. Dried POM and UDOM samples were hydrolyzed with $3 \mathrm{M}$ $\mathrm{HCL}$ at $100^{\circ} \mathrm{C}$ for $5 \mathrm{~h}$. Hydrolyzed samples were neutralized and split into two aliquots. One aliquot was used for analysis of glucosamine, galactosamine, and mannosamine, and the other aliquot was used for analysis of muramic acid. After desalting using a cation exchanger, glucosamine, galactosamine, and mannosamine were separated using isocratic conditions and a mobile phase with $12 \mathrm{mmol} \mathrm{L}^{-1} \mathrm{NaOH}$ and 1 mmol $\mathrm{L}^{-1}$ barium acetate. Muramic acid was measured in a separate chromatographic analysis using isocratic conditions and a mobile phase with $100 \mathrm{mmol} \mathrm{L}^{-1} \mathrm{NaOH}$ and 100 mmol $\mathrm{L}^{-1}$ sodium acetate.

During strong acid hydrolysis, acetyl groups are removed from amino sugars. Acetylated forms of amino sugars are common in nature (e.g., chitin, peptidoglycan), but we do not know whether the amino sugars measured in this study were acetylated prior to acid hydrolysis. The amino sugars measured in this study have six carbon atoms each, and this is the value we used for calculations of amino sugar carbon in samples. Therefore, the values presented herein underestimate amino sugar carbon by as much as $25 \%$ because the acetylated forms of these amino sugars have eight carbon atoms each.

\section{Results}

The recoveries of total hydrolyzable amino sugars from several common polymers ranged from 63 to $78 \%$ (Table 1). Recoveries of glucosamine and galactosamine from polymers linked by glycosidic bonds were uniformly high (74$78 \%$ ). The recovery of muramic acid from peptidoglycan was somewhat lower $(63 \%)$ and likely reflects the occur- 
Table 2. Yields of amino sugars in pure cultures and natural assemblages of organisms collected from various marine environments.

\begin{tabular}{|c|c|c|c|c|c|c|c|}
\hline \multirow[b]{2}{*}{ Culture } & \multirow[b]{2}{*}{ Source } & \multirow{2}{*}{$\begin{array}{l}\text { Class or } \\
\text { family }\end{array}$} & \multirow{2}{*}{$\begin{array}{l}\mathrm{C} / \mathrm{N} \\
\text { atom }\end{array}$} & \multicolumn{4}{|c|}{ Amino sugar $\left(\mathrm{nmol}[\mathrm{mg} \mathrm{C}]^{-1}\right)$} \\
\hline & & & & Ga1N & ManN & GlcN & MA \\
\hline \multicolumn{8}{|l|}{ Phototrophic algae } \\
\hline Heterocapsa niei & CCMP 447 & Dinophyceae & 7.6 & 13.5 & 3.0 & 5.9 & bd \\
\hline Nannochloris sp. & CCMP 518 & Chlorophyceae & 7.0 & bd & 4.7 & 14.6 & bd \\
\hline Emiliania huxleyi & CCMP 373 & Prymnesiophyceae & 8.6 & 5.1 & 0.2 & 9.1 & bd \\
\hline Thalassiosira oceanica & CCMP 1005 & Coscinodiscophyceae & 7.4 & 3.1 & 3.1 & 63.7 & bd \\
\hline \multicolumn{8}{|l|}{ Phototrophic bacteria } \\
\hline Synechococcus bacillaris & CCMP 1333 & Cyanophyceae & 7.4 & 14.1 & 7.3 & 113.0 & 15.1 \\
\hline Synechococcus sp. & CCMP 1334 & Cyanophyceae & 4.8 & 4.3 & 24.9 & 243.2 & 33.9 \\
\hline Trichodesmium sp. & GOM wild & Cyanophyceae & 6.0 & 3.1 & 3.3 & 25.0 & 11.0 \\
\hline \multicolumn{8}{|l|}{ Heterotrophic bacteria } \\
\hline Bacillus subtilis & ATCC 6633 & Bacillaceae & 4.5 & 30.5 & 4.7 & 251.2 & 166.7 \\
\hline Pseudomonas fluorescens & ATCC 13430 & Pseudomonadaceae & 4.1 & 30.9 & bd & 97.4 & 44.6 \\
\hline Natural population & Southern Ocean & Mixed & 6.1 & 10.0 & 2.6 & 23.1 & 4.6 \\
\hline Natural population & Equatorial Pacific & Mixed & 5.8 & 16.9 & 2.4 & 42.9 & 3.0 \\
\hline Natural population & Tokyo Bay & Mixed & 7.7 & 35.8 & 3.3 & 58.8 & nd \\
\hline Natural population & Otsuchi Bay & Mixed & 5.2 & 10.2 & 4.3 & 34.4 & 7.7 \\
\hline \multicolumn{8}{|l|}{ Copepod } \\
\hline Acartia tonsa & GOM female & Crustacea & 4.5 & 32.3 & bd & 457.4 & nd \\
\hline Acartia tonsa & GOM male & Crustacea & 4.4 & 58.0 & bd & $1,210.4$ & nd \\
\hline
\end{tabular}

Abbreviations: GalN, galactosamine; ManN, mannosamine; GlcN, glucosamine; MA, muramic acid; GOM, Gulf of Mexico; bd, below detection; nd, not determined.

rence of peptide as well as glycosidic bonds to this subunit. Overall, these recoveries indicate the hydrolysis is well suited for the analysis of polymers that are likely to be abundant in seawater. No corrections for hydrolysis efficiency were used in this study.

Analyses of total hydrolyzable amino sugars in a variety of marine organisms indicated that galactosamine and glucosamine are common and abundant components of all cells (Table 2), including the cultures of methanogenic Archaea (data not shown). Mannosamine is also widely distributed but is usually less abundant. The diatom, T. oceanica, produces chitin (chitan - partially acetylated) fibrils, which account for the relatively high yield of glucosamine in this marine alga (McLachlan et al. 1965). Amino sugars accounted for $0.1-0.5 \%$ and $0.2-0.6 \%$ of the carbon and nitrogen, respectively, in microalgae. The yields of galactosamine and glucosamine were generally several-fold higher in bacteria than algae. Amino sugars accounted for 0.3-3.9\% and 0.3$2.5 \%$ of the carbon and nitrogen, respectively, in phototrophic and heterotrophic bacteria. Glucosamine was very abundant in the copepod $A$. tonsa because of its chitinous exoskeleton. Amino sugar yields were lower in female copepods, which had threefold greater mass than males. Amino sugars accounted for $\sim 12 \%$ and $\sim 7 \%$ of male copepod carbon and nitrogen, respectively.

Muramic acid was not present in any of the axenically grown algal cultures, but it was present in all phototrophic and heterotrophic bacterial cultures and samples (Table 2). Yields of muramic acid were much higher in the Gram-positive bacterium $B$. subtilis than in the Gram-negative bacteria (Synechococcus, Trichodesmium, Pseudomonas). The cell wall of Gram-positive bacteria is much thicker and accounts for a larger percentage of cellular carbon than in Gram-neg- ative bacteria (Brock et al. 1994). Higher yields of muramic acid were found in cultured Gram-negative bacteria compared with natural populations collected from seawater. It is unclear whether this reflects variability in the contributions of peptidoglycan to cellular carbon or the inclusion of Archaea or detritus during the collection of natural populations of bacteria from seawater. Muramic acid yields varied twofold between the two cultured Synechococcus sp., indicating a considerable variability in the peptidoglycan content of closely related marine bacteria. Muramic acid was not detected in the methanogen cultures (data not shown), which is consistent with previous studies of the molecular composition of cell walls in Archaea (Brock et al. 1994). Yields of muramic acid were typically less than half those of glucosamine in the same bacterium. These amino sugars occur in a $1: 1$ ratio in peptidoglycan, indicating the majority of the glucosamine in Gram-negative bacteria is not associated with this cell wall polymer.

Galactosamine and glucosamine were the most abundant amino sugars in POM collected from the Pacific Ocean (Table 3). Seawater concentrations of galactosamine and glucosamine in POM ranged from 0.07 to $1.09 \mathrm{nmol} \mathrm{L}^{-1}$, with highest concentrations in surface waters. The ratio of glucosamine: galactosamine ( $\mathrm{GlcN}$ : GalN) ranged from 1.6 to 2.5 and averaged 1.9. Mannosamine was detected in POM samples, but it was in low concentration and could not be reliably quantified in the presence of high galactosamine concentrations. Muramic acid was also present in low concentration, but it was quantified in a separate chromatographic analysis (see Methods). The carbon-normalized yields of galactosamine, glucosamine, and muramic acid in POM (Table 3) were similar to yields in natural populations of marine bacteria (Table 2). Glucosamine was much more abundant 
Table 3. Concentrations and yields of amino sugars in particulate organic matter (POM) from the Pacific Ocean.

\begin{tabular}{|c|c|c|c|c|c|c|c|c|}
\hline $\begin{array}{l}\text { Depth } \\
(\mathrm{m})\end{array}$ & $\begin{array}{c}\text { POC } \\
(\mu \mathrm{mol} \mathrm{L}-1)\end{array}$ & $\begin{array}{l}\mathrm{C} / \mathrm{N} \\
\text { atom }\end{array}$ & $\begin{array}{c}\text { GalN } \\
\left(\mathrm{nmol} \mathrm{L}{ }^{-1}\right)\end{array}$ & $\begin{array}{c}\text { GalN } \\
\left(\mathrm{nmol}[\mathrm{mg} \mathrm{C}]^{-1}\right)\end{array}$ & $\begin{array}{c}\text { GlcN } \\
\left.(\mathrm{nmol} \mathrm{L})^{-1}\right)\end{array}$ & $\begin{array}{c}\text { GlcN } \\
\left(\mathrm{nmol}[\mathrm{mg} \mathrm{C}]^{-1}\right)\end{array}$ & $\begin{array}{c}\text { MA } \\
\left.(\mathrm{nmol} \mathrm{L})^{-1}\right)\end{array}$ & $\begin{array}{c}\text { MA } \\
\left(\mathrm{nmol}[\mathrm{mg} \mathrm{C}]^{-1}\right)\end{array}$ \\
\hline \multicolumn{9}{|c|}{$2^{\circ} \mathrm{S}, 140^{\circ} \mathrm{W}$} \\
\hline 2 & 1.02 & 7.7 & 0.52 & 42.3 & 1.05 & 85.2 & 0.071 & 5.81 \\
\hline 100 & 0.46 & 7.0 & 0.10 & 17.0 & 0.24 & 42.3 & 0.033 & 5.92 \\
\hline 400 & 0.71 & 8.0 & 0.25 & 29.7 & 0.44 & 52.0 & 0.027 & 3.21 \\
\hline 4,000 & 0.35 & 7.2 & 0.07 & 16.6 & 0.11 & 26.4 & 0.012 & 2.88 \\
\hline \multicolumn{9}{|c|}{$12^{\circ} \mathrm{S}, 135^{\circ} \mathrm{W}$} \\
\hline 2 & 0.83 & 7.7 & 0.61 & 55.4 & 1.09 & 99.5 & 0.065 & 5.93 \\
\hline 100 & 0.82 & 7.4 & 0.31 & 31.8 & 0.65 & 66.7 & 0.035 & 3.54 \\
\hline 200 & 0.32 & 7.6 & 0.09 & 23.7 & 0.17 & 43.0 & 0.017 & 4.44 \\
\hline 375 & 0.43 & 8.6 & 0.14 & 27.1 & 0.25 & 49.6 & 0.010 & 1.91 \\
\hline 4,000 & 0.32 & 7.0 & 0.07 & 17.3 & 0.12 & 32.1 & 0.024 & 6.18 \\
\hline
\end{tabular}

(5-25-fold) than muramic acid, indicating most glucosamine was not associated with peptidoglycan.

Total hydrolyzable amino sugars were analyzed in UDOM samples from various locations and depths in three ocean basins (Table 4). Surface water concentrations of galactosamine and glucosamine in the UDOM size fraction ranged from 10 to $36 \mathrm{nmol} \mathrm{L}^{-1}$ and 17 to $56 \mathrm{nmol} \mathrm{L}{ }^{-1}$, respectively. Deep water concentrations were less variable and ranged from 2.3 to $5.8 \mathrm{nmol} \mathrm{L} \mathrm{L}^{-1}$ and 3.8 to $5.8 \mathrm{nmol} \mathrm{L} \mathrm{L}^{-1}$, respectively. Surface water concentrations of galactosamine and glucosamine were typically higher in the Pacific and Atlantic compared with the Arctic. As with POM samples, mannosamine was detected in UDOM samples, but it was in low concentration and could not be reliably quantified in the presence of high galactosamine concentrations. Muramic acid concentrations were low and ranged from 0.12 to 0.78

Table 4. Concentrations and yields of amino sugars in ultrafiltered dissolved organic matter (UDOM).

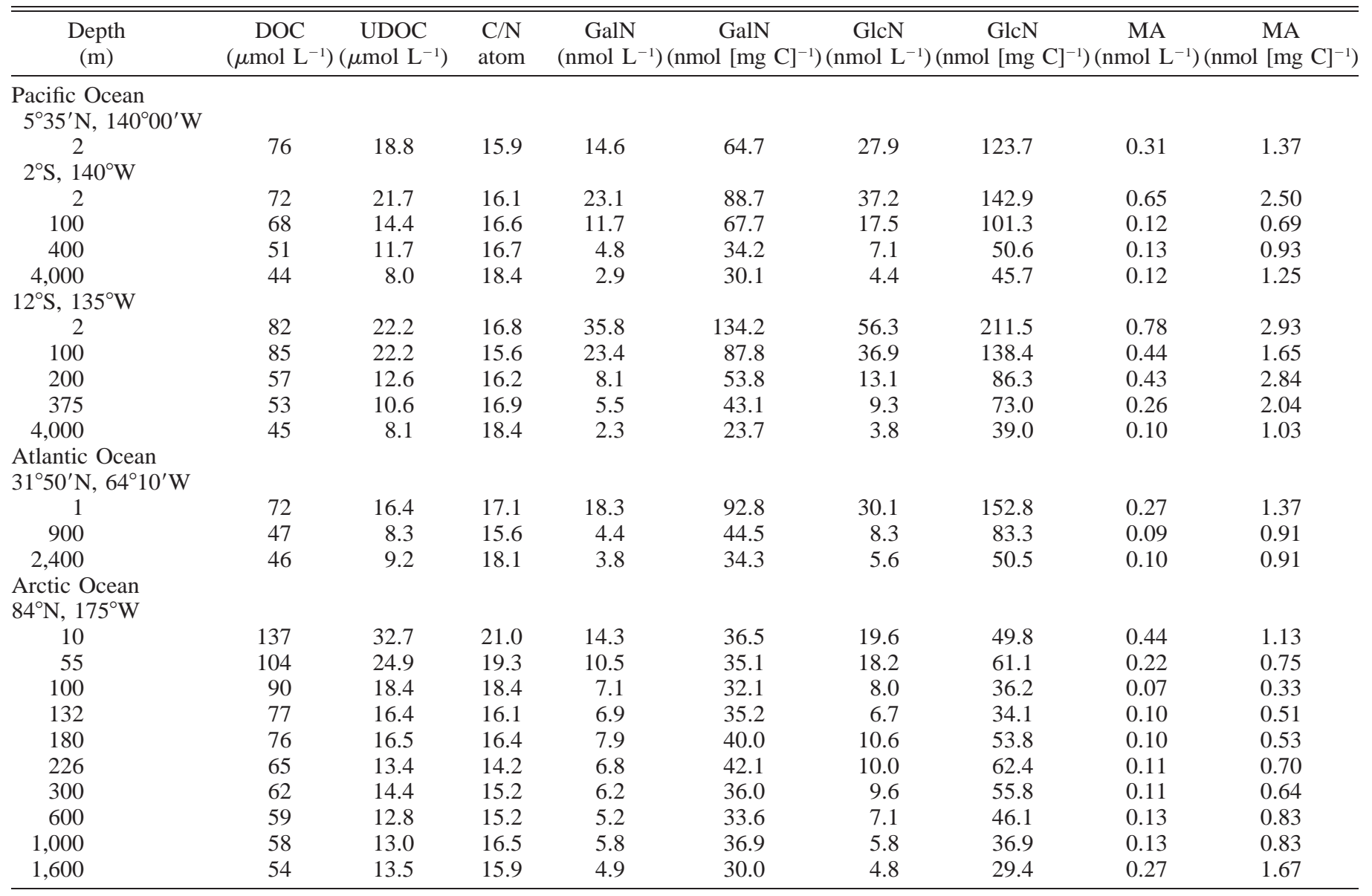



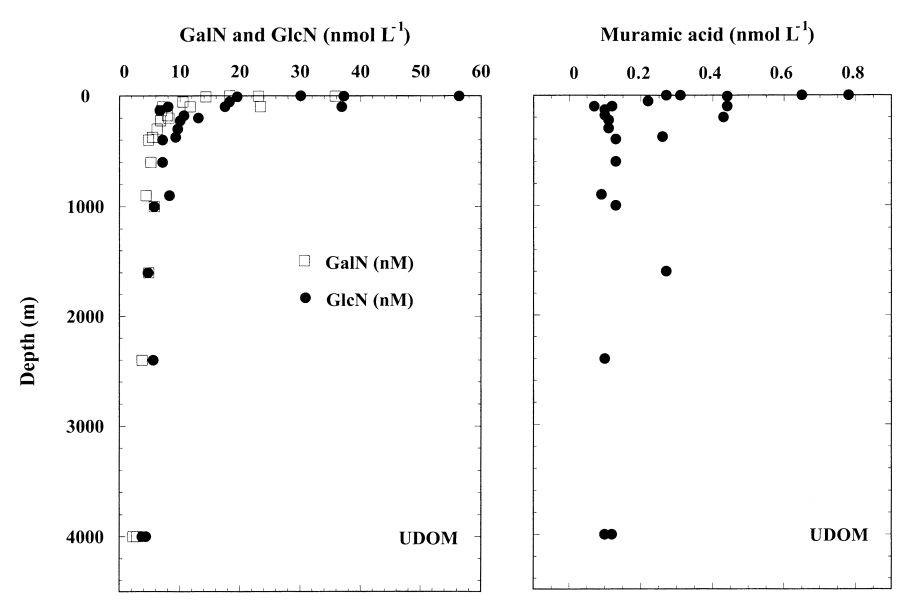

Fig. 1. Concentrations ( $\mathrm{nmol} \mathrm{L} \mathrm{L}^{-1}$ ) of galactosamine (GalN), glucosamine $(\mathrm{GlcN})$, and muramic acid in ultrafiltered dissolved organic matter (UDOM) from the Pacific, Atlantic, and Arctic Oceans.

nmol $\mathrm{L}^{-1}$ in surface waters and 0.10 to $0.27 \mathrm{nmol} \mathrm{\textrm {L } ^ { - 1 }}$ in deep waters.

Composite depth profiles of total hydrolyzable galactosamine, glucosamine, and muramic acid concentrations in the UDOM size fraction from the Pacific, Atlantic, and Arctic Oceans are presented in Fig. 1. The profiles indicate similar concentrations and depth trends among ocean basins. Surface water concentrations were 5-10-fold higher than deep water concentrations, indicating a major surface water source for these amino sugars. Glucosamine and galactosamine were found in similar relative proportions in all UDOM samples, and a surprisingly narrow range of GlcN : GalN values (1-2) was observed (Fig. 2). The average GlcN : GalN value in UDOM was 1.5 and is similar to the average value (1.9) in POM. The ratio of glucosamine: muramic acid $(\mathrm{GlcN}$ : MA) in UDOM exhibited a wide range of values (18-146) with an average value of 70 (Fig. 2). These high values indicate most of the glucosamine in UDOM is not associated with the bacterial cell wall polymer peptidoglycan.

Carbon-normalized yields of galactosamine, glucosamine, and muramic acid in POM and UDOM from the same water samples are compared at two stations $\left(12^{\circ} \mathrm{S}, 135^{\circ} \mathrm{W}\right.$ and $2^{\circ} \mathrm{S}$, $140^{\circ} \mathrm{W}$ ) in the Pacific Ocean (Figs. 3, 4). Galactosamine and glucosamine yields are consistently lower in POM compared to UDOM. Yields of galactosamine and glucosamine in POM and UDOM decrease with increasing depth, although the change is greater in UDOM. Unlike galactosamine and glucosamine yields, muramic acid yields were higher in POM than UDOM. Muramic acid yields in POM and UDOM were variable and did not exhibit a consistent depthrelated trend. Based on these overall patterns and distributions, it appears that galactosamine and glucosamine are closely associated in marine organic matter.

Total hydrolyzable amino sugars accounted for $0.7-2.5 \%$ of the carbon and $2.2-7.1 \%$ of the nitrogen in UDOM from surface waters (Fig. 5). About 0.6 and $1.5 \%$ of the carbon and nitrogen in UDOM from deep water was accounted for as amino sugars. Similar depth-related trends were observed

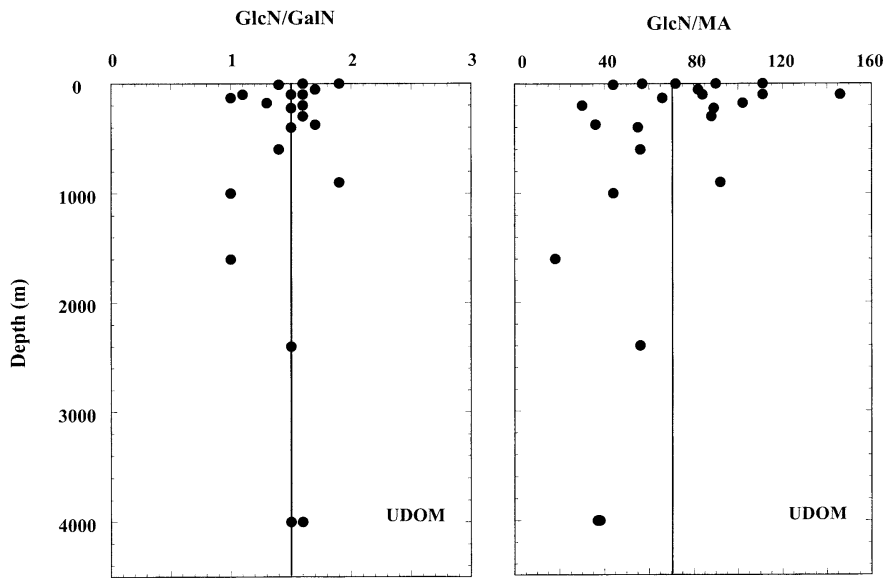

Fig. 2. Molar ratios of glucosamine: galactosamine $(\mathrm{GlcN}$ : GalN) and glucosamine : muramic acid (GlcN : MA) in UDOM from the Pacific, Atlantic, and Arctic Oceans. Vertical lines represent mean values.

with POM. Amino sugars accounted for $0.34-1.30 \%$ of organic carbon and $0.38-1.61 \%$ of organic nitrogen in POM.

The average carbon-normalized yields of galactosamine, glucosamine, and muramic acid in marine phytoplankton (algae), bacterioplankton, POM, and UDOM from surface and deep waters are presented in Fig. 6. The yields of galactosamine and glucosamine in surface water POM are greater than those in marine microorganisms. This could indicate an enrichment of these amino sugars during the decomposition of particulate material, or it could indicate other sources of amino sugar-rich particles, such as zooplankton. An even greater enrichment of amino sugars is observed in surface water UDOM. Again, it is not clear whether this trend is indicative of variable sources or diagenesis. The galactosamine and glucosamine yields in deep water POM and UDOM are considerably lower than surface water counterparts, and we interpret this as a diagenetic trend.

Muramic acid yields follow a very different pattern from that of galactosamine and glucosamine (Fig. 6). Bacteria are the only known source of this amino sugar, and yields of muramic acid are highest in marine bacteria. The POM samples include marine bacteria as well as other organisms and nonliving particles, and these samples have the next highest yields of muramic acid followed by UDOM. Muramic acid yields in POM and UDOM decrease with depth, as was observed with the other amino sugars.

\section{Discussion}

Abundance and distribution of amino sugars-Glucosamine and galactosamine, the most common amino sugars, were measured in all marine phytoplankton, bacterioplankton, and zooplankton analyzed. Glucosamine was particularly abundant in marine copepods, accounting for as much as $12 \%$ of biomass carbon. These two amino sugars were measured in all samples of marine particulate and dissolved organic matter, demonstrating their widespread distribution in the ocean. Glucosamine and galactosamine occurred in fairly constant proportion (GlcN : GalN; 1.0-2.5) in all POM and 
Galactosamine (nmol mg $\mathrm{C}^{-1}$ )

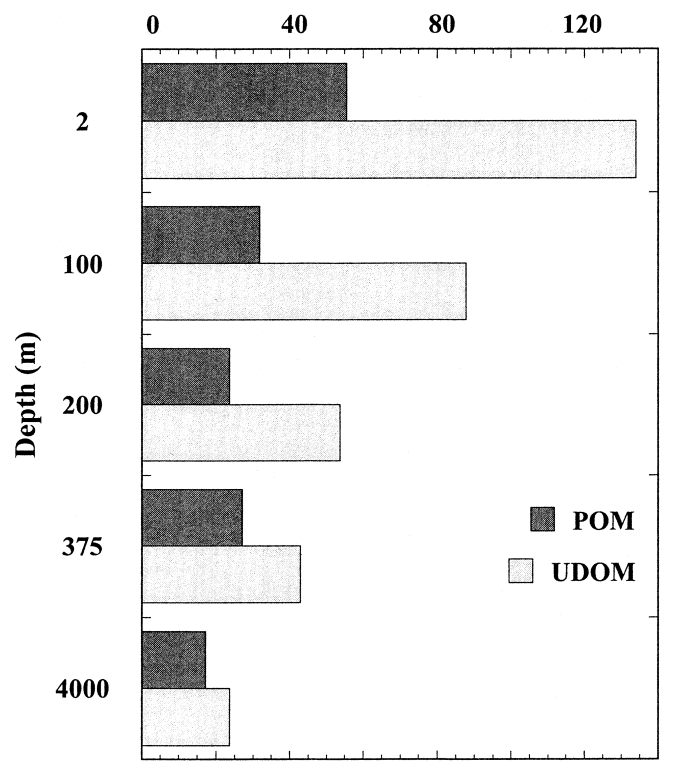

Glucosamine (nmol mg C ${ }^{-1}$ )

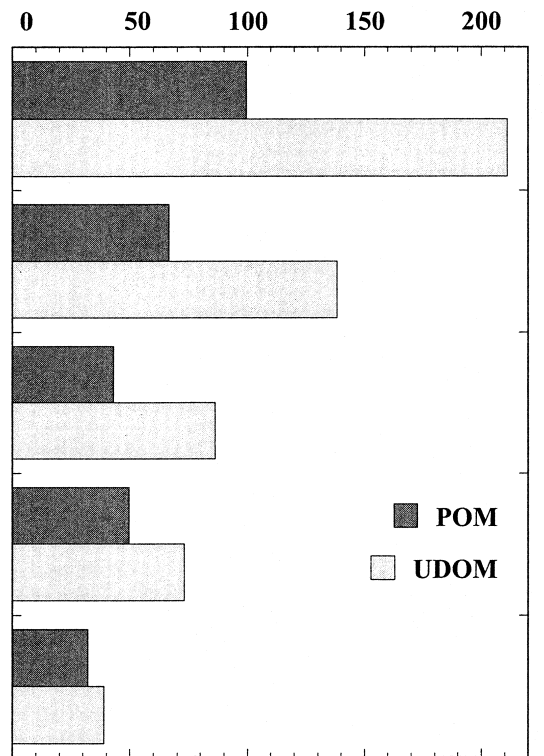

Muramic Acid (nmol mg C ${ }^{-1}$ )

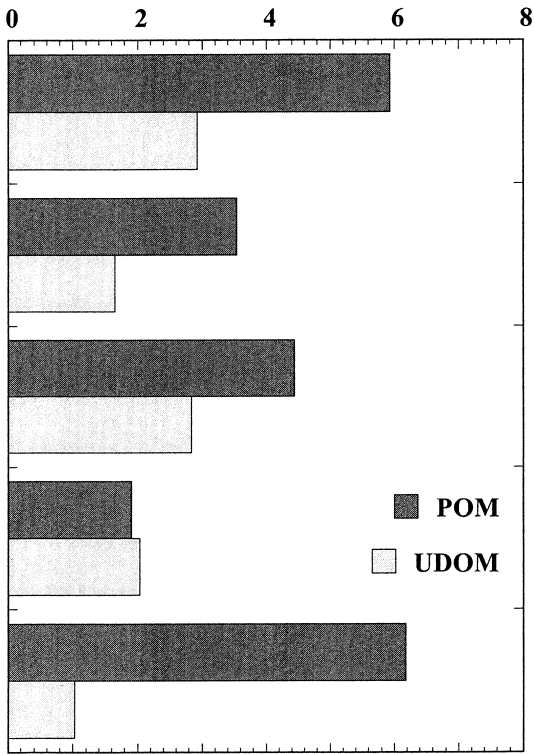

Fig. 3. Carbon-normalized yields of galactosamine, glucosamine, and muramic acid in particulate organic matter (POM) and ultrafiltered DOM (UDOM) from $12^{\circ} \mathrm{S}, 135^{\circ} \mathrm{W}$ in the Pacific Ocean.

UDOM samples. Total hydrolyzable amino sugars accounted for $0.1-1.5 \%$ of organic carbon in marine plankton and suspended particulate material. They were more abundant in the dissolved phase $(<0.1 \mu \mathrm{m})$, accounting for $0.6-2.5 \%$ of organic carbon in UDOM. Seawater concentrations of amino sugars in POM and UDOM were typically 5-10-fold higher in surface compared to deep waters, and carbon-normalized yields were typically 2-4-fold higher, indicating amino sugars are rapidly cycled in the upper ocean.

In a previous study of surface water particulate material in the 75-150- $\mu \mathrm{m}$ size class from high latitude regions of the south Atlantic, glucosamine yields were highly variable, ranging from 39 to $825 \mathrm{nmol}(\mathrm{mg} \mathrm{C})^{-1}$, and galactosamine was not detected in most samples (Müller et al. 1986). In

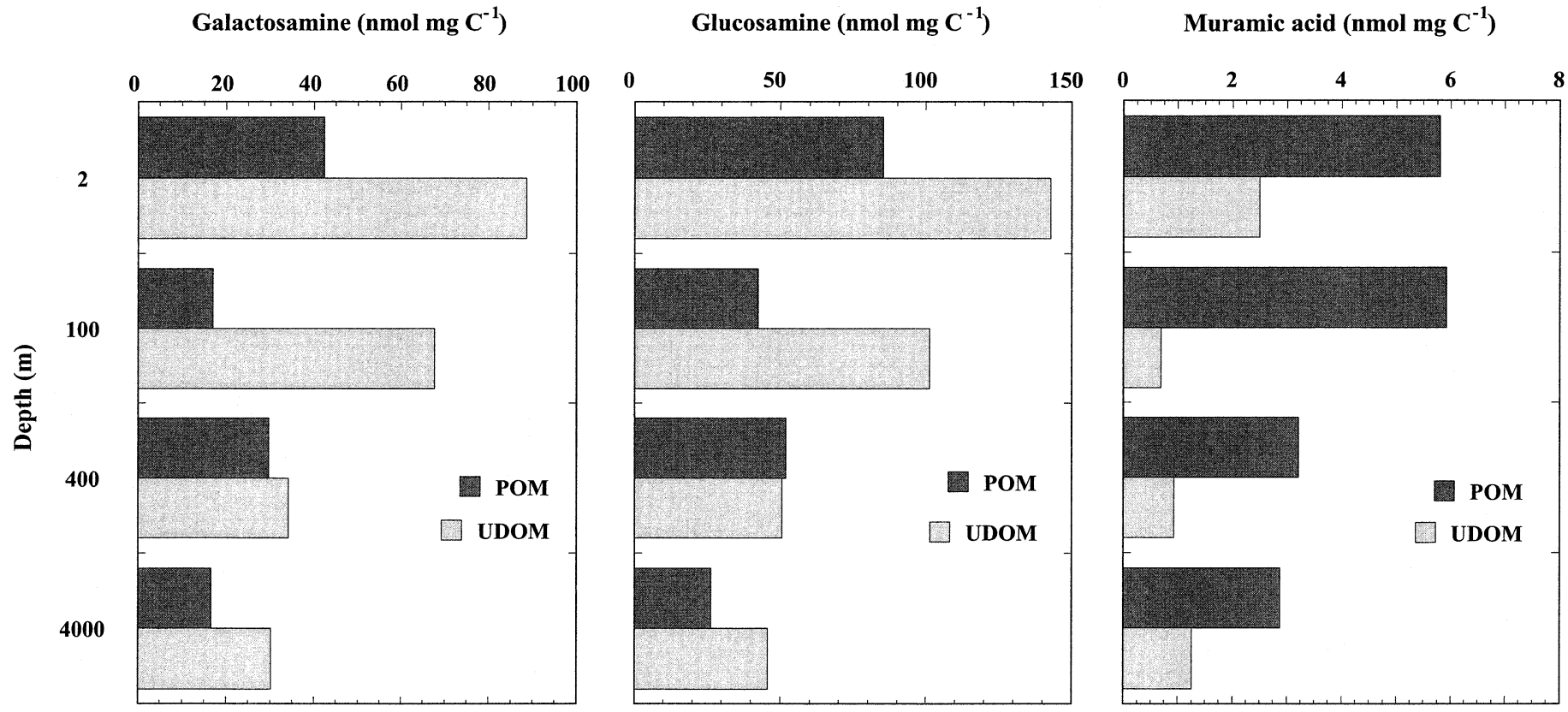

Fig. 4. Carbon-normalized yields of galactosamine, glucosamine, and muramic acid in POM and UDOM from $2^{\circ} \mathrm{S}, 140^{\circ} \mathrm{W}$ in the Pacific Ocean. 

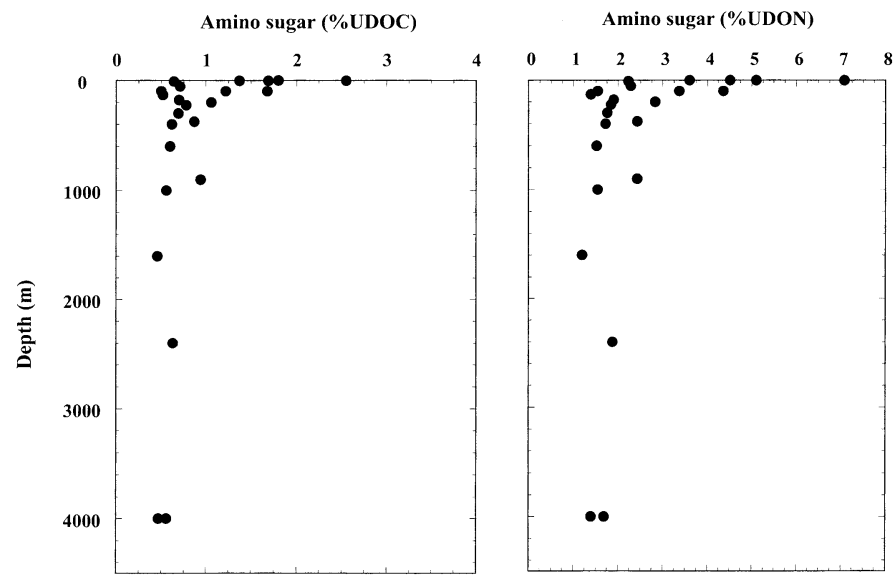

Fig. 5. Percentages of ultrafiltered dissolved organic carbon (UDOC) and nitrogen (UDON) in galactosamine, glucosamine, and muramic acid. Samples are the same as those in Fig. 1.

the present study, yields of glucosamine in POM (0.1-60 $\mu \mathrm{m}$ size class) from surface water in the tropical Pacific ranged from 85 to $100 \mathrm{nmol}(\mathrm{mg} \mathrm{C})^{-1}$, and galactosamine was relatively abundant. Differences between these studies are likely related to the different particle sizes analyzed and the greater abundance of large zooplankton in the south Atlantic compared to the tropical Pacific. The high values in the south Atlantic suggest substantial contributions of chitinous material from zooplankton (Müller et al. 1986). These authors also observed diel variations in the composition of surface particulate material that were indicative of the ver- tical migration of zooplankton to surface waters at night. Galactosamine was measured in deep sediment trap samples from the Drake Passage, and GlcN: GalN ratios in trap material ranged from 4.1 to 4.7 (Müller et al. 1986). Galactosamine was also abundant in sediments from the Weddell Sea and Bransfield Strait, where GlcN : GalN ratios of $\sim 1.2$ were measured, and amino sugars accounted for $0.6-1.4 \%$ of organic carbon in surface sediments (Liebezeit 1993).

Total hydrolyzable neutral sugars were analyzed previously in many of the POM and UDOM samples $\left(12^{\circ} \mathrm{S}\right.$, $135^{\circ} \mathrm{W}$ and $2^{\circ} \mathrm{S}, 140^{\circ} \mathrm{W}$ ) analyzed here for amino sugars (Skoog and Benner 1997). Galactose and glucose concentrations in POM ranged from 0.1 to $3.6 \mathrm{nmol} \mathrm{L}^{-1}$ and 1.5 to $7.3 \mathrm{nmol} \mathrm{L}{ }^{-1}$, respectively. Galactosamine and glucosamine concentrations in POM were less abundant and ranged from 0.1 to $0.6 \mathrm{nmol} \mathrm{L}{ }^{-1}$ and 0.1 to $1.1 \mathrm{nmol} \mathrm{L}{ }^{-1}$, respectively. In total, the seven measured neutral sugars accounted for $\sim 10$-fold greater percentage of POC (3.7-12.4\%, Skoog and Benner 1997) than amino sugars. Galactose and glucose concentrations in UDOM ranged from 3.8 to $72 \mathrm{nmol} \mathrm{L}^{-1}$ and 4.0 to $65 \mathrm{nmol} \mathrm{L}^{-1}$, respectively. Galactosamine and glucosamine concentrations in UDOM were slightly less abundant and ranged from 2.3 to $36 \mathrm{nmol} \mathrm{L}{ }^{-1}$ and 3.8 to $56 \mathrm{nmol} \mathrm{L}^{-1}$, respectively. In total, neutral sugars accounted for $\sim 3.5$-fold greater percentage of ultrafiltered dissolved organic carbon (UDOC: 1.5 to $9.4 \%$, Skoog and Benner 1997) than amino sugars. Neutral and amino sugars together accounted for 12.8 and $4.3 \%$ of the POC in surface and deep water, respectively. Amino sugars accounted for $8.7 \pm 1.2 \%$ (mean $\pm \mathrm{SD}$ ) of the sum of neutral and amino sugar carbon in POM samples.

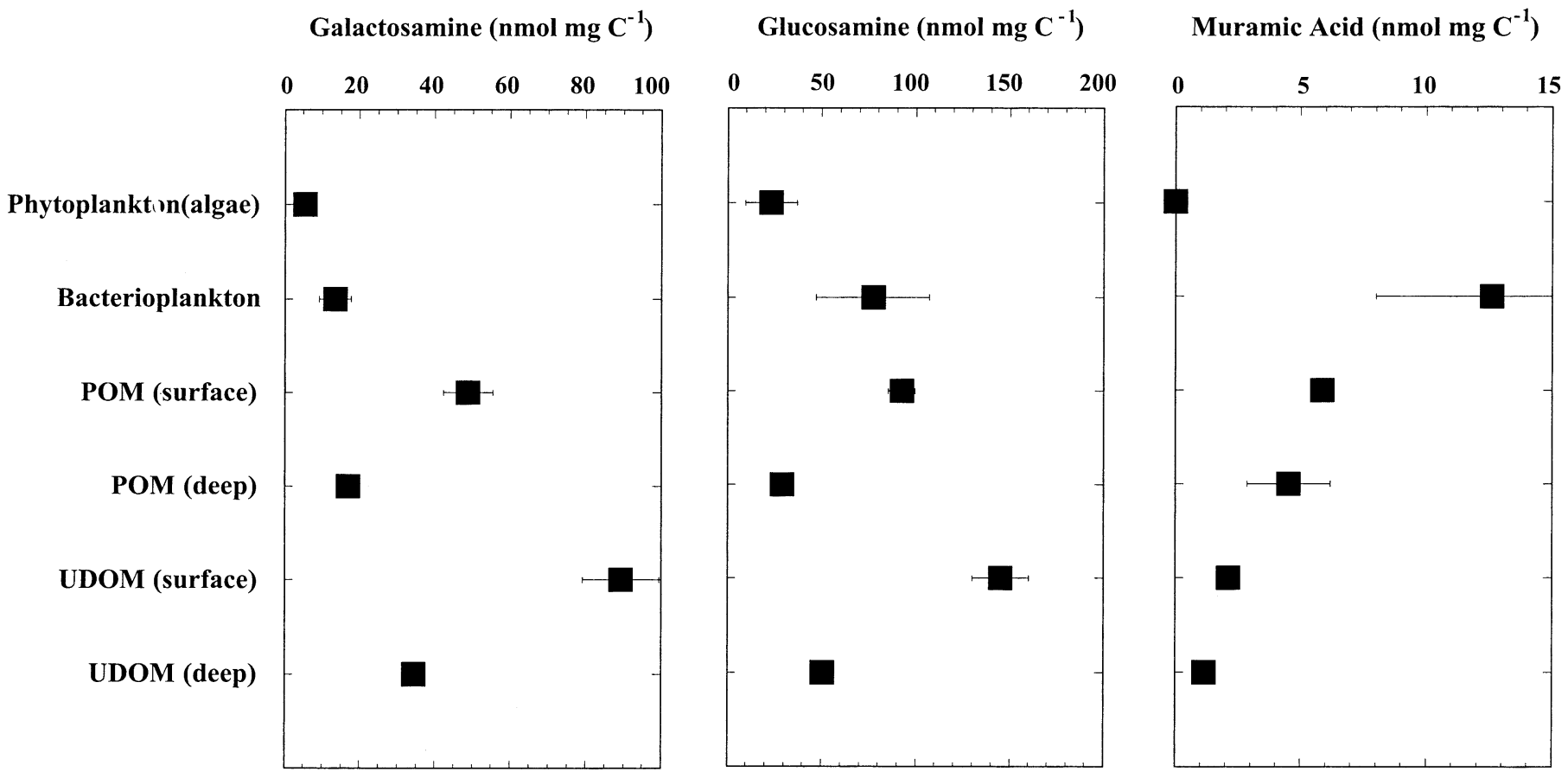

Fig. 6. Average carbon-normalized yields of galactosamine, glucosamine, and muramic acid in marine plankton (algae and bacteria from Table 2), POM, and UDOM from surface and deep waters. Surface water yields of galactosamine and glucosamine in the Arctic Ocean were lower than those in the Pacific and Atlantic Oceans (see Table 4) and were not included in the calculations. Bars represent the standard error of the mean. 
Neutral and amino sugars together accounted for 9.7 and $2.3 \%$ of the UDOC in surface and deep water, respectively. Amino sugars accounted for $22.9 \pm 4.6 \%$ of the sum of neutral and amino sugar carbon in UDOM samples.

Amino sugars are unique among the carbohydrates as nitrogen-bearing molecules. They account for a substantial percentage (2-7\%) of ultrafiltered dissolved organic nitrogen (UDON) and are therefore likely important components of the marine $\mathrm{N}$ cycle. For comparison, total hydrolyzable amino acids accounted for 14-28\% of UDON in samples that were similarly collected from the Pacific Ocean (McCarthy et al. 1996). Amino acids clearly account for a much greater percentage of marine organic nitrogen than amino sugars, but dissolved amino sugar concentrations and carbon-normalized yields decrease more rapidly with depth than amino acid concentrations and yields, suggesting amino sugars are more efficiently cycled in the upper water column (Benner 2002).

Analyses by nuclear magnetic resonance (NMR) spectroscopy of similar UDOM samples from the Pacific Ocean indicate that carbohydrates account for $\sim 50 \%$ and $\sim 25 \%$ of UDOC in surface and deep water, respectively (Benner et al. 1992). Total hydrolyzable neutral and amino sugars together account for only $\sim 20 \%$ and $\sim 10 \%$ of the carbohydrate carbon indicated by NMR in UDOM from surface and deep water, respectively. Acidic sugars (e.g., uronic acids) are another important group of carbohydrates not characterized in this study, but recent spectrophotometric analyses of uronic acids indicate they are no more abundant than neutral or amino sugars (Hung et al. 2001). It is now apparent that most of the carbohydrate-type structures in UDOM indicated by NMR are not characterized at the molecular level using existing hydrolytic and chromatographic methods. The hydrolytic conditions chosen for carbohydrate analyses need to be sufficient to cleave hydrolysis-resistant bonds without altering the structures of the carbohydrates released. It is possible that our current methods fail to meet these criteria with natural organic matter, resulting in low carbohydrate recoveries after acid hydrolysis. Another possibility is that carbohydrates are modified by biological and photochemical processes in seawater (Benner and Biddanda 1998; Obernosterer et al. 1999; Ogawa et al. 2001), resulting in structures that retain biochemical functional groups (e.g., C-O and $\mathrm{O}-\mathrm{C}-\mathrm{O}$ ) characteristic of carbohydrates and detected by NMR but lose their molecular identity. It is also conceivable that unusual carbohydrates not characterized using current analytical procedures are the dominant carbohydrates in seawater. Unraveling this mystery is critical for gaining a better understanding of the source and reactivity of a large fraction of marine DOM.

Reactivity of amino sugars-Much can be learned about the reactivity of organic matter by comparing depth-related trends in the concentrations of carbon and specific biomolecules (Benner 2002). Such comparisons led Liebezeit (1993) to suggest that chitinous particulate material is largely produced and consumed in the upper ocean. Comparison of the concentrations of POC and total hydrolyzable amino sugars in surface and oxygen-minimum (375-400 m) waters of the tropical Pacific indicates that decreases in concentrations of amino sugars were $\sim 2$-fold greater than decreases in POC. Based on the same comparison for UDOM, decreases in concentrations of amino sugars were $\sim 2.5$-fold greater than decreases in UDOC. These comparisons indicate that amino sugars are considerably more reactive than bulk carbon in upper ocean particulate and dissolved organic matter. A similar analysis of total hydrolyzable neutral sugars in these samples (Skoog and Benner 1997) indicates neutral sugars are of similar reactivity as amino sugars. Overall, carbohydrates are among the most abundant and reactive components of the upper ocean carbon and nitrogen cycles.

Glucosamine and galactosamine occur in relatively constant proportion in POM $(\sim 1.9)$ and UDOM $(\sim 1.5)$ from diverse geographic regions, suggesting these amino sugars are closely associated and have similar reactivities. Similar GlcN: GalN ratios of $\sim 1.2$ and $\sim 1.9$ were observed in marine sediments and DOM derived from bacteria, respectively (Liebezeit 1993; Ogawa et al. 2001). Previous studies of marine POM and DOM noted fairly constant neutral sugar compositions among samples from different ocean basins (McCarthy et al. 1996; Aluwihare et al. 1997; Borch and Kirchman 1997; Skoog and Benner 1997; Kirchman et al. 2001). This narrow range of neutral and amino sugar compositions in marine POM and DOM is surprising. The biological sources of these carbohydrates have quite variable compositions. Moreover, these compositional similarities are common to very reactive organic matter that cycles rapidly in the upper ocean, as well as refractory organic matter that persists in the deep ocean. These observations indicate that compositional uniformity is rapidly imprinted in marine organic matter during early diagenesis. Results from a recent study monitoring neutral sugar compositions during experimental phytoplankton blooms (Meon and Kirchman 2001) also suggest that decomposition processes play an important role in shaping the carbohydrate composition of organic matter in the ocean.

Muramic acid, peptidoglycan, and bacterial contributions to marine organic matter-Peptidoglycan is a unique cell wall polymer of bacteria that consists of glycan strands of a repeating disaccharide ( $N$-acetyl-glucosamine and $N$-acetylmuramic acid) covalently cross-linked by peptide side chains composed of both L- and D-amino acids. Muramic acid is only found in peptidoglycan, where it is linked to both the glycan strand and the peptide side chain. The peptide side chains vary in amino acid composition, length, and position of cross-linking, whereas muramic acid occurs in the constant stoichiometry of one residue per subunit of peptidoglycan (Schleifer and Kandler 1972). These characteristics make muramic acid an ideal biomarker for peptidoglycan.

Yields of muramic acid were highly variable among the cultured bacteria analyzed in this study. Previous analyses of muramic acid in terrestrial and marine bacteria have noted similar yields and variability (Moriarty 1977; Mimura and Romano 1985). The greatest difference in muramic acid yields is between Gram-positive and Gram-negative cells, with Gram-positive cells having 5- to 10-fold greater yields of muramic acid (Moriarty 1977; this study). Most bacteria in seawater and marine sediments are Gram-negative (Moriarty and Hayward 1982; Giovannoni 2000), and based on 
analyses of cultured Gram-negative marine bacteria, we expected muramic acid yields ranging from 15 to $35 \mathrm{nmol}(\mathrm{mg}$ C) $)^{-1}$ (Moriarty 1977; Mimura and Romano 1985; this study). The yield $\left(11 \mathrm{nmol}\right.$ muramic acid $\left(\mathrm{mg} \mathrm{C}^{-1}\right)$ in a population of Trichodesmium sp. collected during a bloom in Gulf of Mexico surface water is similar to the lower values observed in cultures. However, muramic acid yields (3-5 nmol muramic acid $\left(\mathrm{mg} \mathrm{C}^{-1}\right)$ in natural populations of prokaryotic microorganisms collected from the open ocean were particularly low in the present study. These low muramic acid yields in size-fractionated samples could result from marine bacteria with unusually thin cell walls or the presence of detrital material. Members of the domain Archaea are reported to be abundant in the deep ocean (Karner et al. 2001), but it is unlikely they were included with bacteria in the surface water samples we analyzed. Archaea do not contain muramic acid in their cell walls (Brock et al. 1994), so inclusion of Archaea in samples would result in lower yields of muramic acid.

The yields of muramic acid in POM were relatively high and similar to those in the natural populations of marine bacteria analyzed in this study. Based on direct counts of bacteria (prokaryotes) in the initial water samples collected for POM isolation (Benner et al. 1997), we estimated the amount of muramic acid in POM associated with bacterial biomass. We assumed that all cells counted were bacteria (i.e., no Archaea) and therefore had muramic acid in their cell walls. Karner et al. (2001) recently found that Archaea comprise about half of the total direct count of cells in deep water, so our calculations provide a maximal estimate of muramic acid associated with bacterial cells in deep water. For these calculations, we used $12.4 \mathrm{fg} \mathrm{C}$ cell $^{-1}$ for the carbon content of marine bacteria (Fukuda et al. 1998) and 12.6 $\mathrm{nmol}(\mathrm{mg} \mathrm{C})^{-1}$ for the muramic acid yield of marine bacteria. This muramic acid yield is the average of all cultured and natural populations of marine bacteria analyzed in this study. Based on this estimate, most of the muramic acid recovered in the POM size class $(0.1-60 \mu \mathrm{m})$ was associated with nonliving particles. On average, 3.4-fold more muramic acid was recovered in POM than could be accounted for in bacterial cells. Only $10-15 \%$ of the muramic acid in the two POM samples from $4,000 \mathrm{~m}$ was attributable to intact bacterial cells. These data provide strong evidence of a substantial reservoir of detrital particulate material of bacterial origin throughout the ocean water column. This bacterial detritus includes cell wall material with fragments of peptidoglycan, as indicated by the occurrence of muramic acid. Various processes, including viral lysis and protozoan grazing, could lead to the formation of bacterial detritus (Fuhrman 2000; Nagata 2000; Strom 2000). These results indicate bacterial detritus is abundant and likely accounts for a substantial fraction of the submicron and colloidal particles observed in seawater (Koike et al. 1990; Wells and Goldberg 1991).

Several recent studies have identified specific biochemicals of bacterial origin in marine DOM, including a membrane protein (Tanoue et al. 1995), D-amino acids (McCarthy et al. 1998), and components of lipopolysaccharides (Wakeham et al. in press). All of these biomarkers are components of bacterial cell wall complexes. Based on the abundance of specific D-amino acids in marine UDOM, McCarthy et al. (1998) suggested that peptidoglycan was an abundant and important component of marine DON. In the present study, muramic acid was measured in all UDOM samples, confirming the ubiquitous occurrence of peptidoglycan in marine DOM. However, yields of muramic acid in UDOM are more than 10-fold lower than those of D-Ala, a common component of the peptide side chain in peptidoglycan. Muramic acid and D-Ala are typically found in equimolar yields in peptidoglycan (Schleifer and Kandler 1972). Every subunit of peptidoglycan includes muramic acid, so there is much more D-Ala in UDOM than can be accounted for in peptidoglycan. It appears the D-amino acids in UDOM are remnants derived from bacterial cell walls rather than components of intact subunits of peptidoglycan. Recent studies of the production and decomposition of DOM derived from marine bacteria indicate that the glycan component of peptidoglycan is relatively rapidly degraded (Ogawa et al. 2001). It is unclear why the peptide side chains of peptidoglycan would be more resistant to decomposition than the glycan strand. Further studies of the decomposition of bacterial cell walls in seawater and the sources of D-amino acids are needed to explain the prevalence of D-amino acids in marine DOM.

Galactosamine and glucosamine were abundant in POM and UDOM and could be of bacterial origin, but these compounds have many potential sources. These amino sugars were present in all organisms analyzed in this study, including members of the Bacteria, Archaea and Eukarya domains. As shown in the present study, marine phytoplankton and zooplankton that produce chitin are rich in glucosamine and have high (>14) GlcN: GalN ratios. Müller et al. (1986) found high concentrations of glucosamine and trace concentrations of galactosamine in large $(>75 \mu \mathrm{m})$ surface water particles, indicating they were largely composed of chitinous material and derived from zooplankton. In contrast, deep marine sediments have GlcN: GalN ratios of 1-2, indicating they are largely derived from heterotrophic microorganisms (Liebezeit 1993). We observed GlcN : GalN ratios of 1.0-2.5 in marine POM and UDOM from various depths and geographic regions, and this could be indicative of a microbial origin. Recent analyses of marine UDOM by direct temperature-resolved mass spectrometry noted the presence of $N$ acetyl amino sugars (Boon et al. 1998). These authors suggested a bacterial origin for most polysaccharides in UDOM based on characteristic spectra produced under various ionization conditions and the occurrence of methylated neutral sugars, which are biomarkers of bacterial origin. Glucosamine and galactosamine were important components of refractory DOM derived from bacteria, and they remained in fairly constant proportion $(\sim 1.9$, respectively) during a yearlong decomposition study (Ogawa et al. 2001). The macromolecular identity of this polymeric material with relatively low and constant GlcN: GalN ratios remains unknown. Its biological origin is also uncertain, but there is growing evidence of a major prokaryotic source in the ocean.

\section{References}

Aluwihare, L. I., D. J. Repeta, And R. F. Chen. 1997. A major biopolymeric component to dissolved organic carbon in surface seawater. Nature 387: 166-169. 
BenNer, R. 2002. Chemical composition and reactivity, p. 59-90. In D. Hansell and C. Carlson [eds.], Biogeochemistry of marine dissolved organic matter. Academic.

- 2 AND B. BIDDANDA. 1998. Photochemical transformations of surface and deep marine dissolved organic matter: Effects on bacterial growth. Limnol. Oceanogr. 43: 1373-1378.

- AND M. STROM. 1993. A critical evaluation of the analytical blank associated with DOC measurements by high-temperature catalytic oxidation. Mar. Chem. 41: 153-160.

$\longrightarrow$, J. D. Pakulski, M. McCarthy, J. I. Hedges, and P. G. HATCHER. 1992. Bulk chemical characterization of dissolved organic matter in the ocean. Science 255: 1561-1564.

- B. BiddANDA, B. BlaCK, AND M. MCCARTHY. 1997. Abundance, distribution, and stable carbon and nitrogen isotopic compositions of marine organic matter isolated by tangential-flow ultrafiltration. Mar. Chem. 57: 243-263.

BidDanda, B. A. 1995. Trichodesmium bloom in Gulf of Mexico, summer 1995. IOC/UNESCO Harmful Algae News 12/13.

- AND R. BENNER. 1997. Carbon, nitrogen and carbohydrate fluxes during the production of particulate and dissolved organic matter by marine phytoplankton. Limnol. Oceanogr. 42: 506-518.

Boon, J. J., V. A. Klap, And T. I. Eglinton. 1998. Molecular characterization of microgram amounts of oceanic colloidal organic matter by direct temperature-resolved ammonia chemical ionization mass spectrometry. Org. Geochem. 29: 1051-1061.

BorCh, N. H., AND D. L. KIRChMAN. 1997. Concentration and composition of dissolved combined neutral sugars (polysaccharides) in seawater determined by HPLC-PAD. Mar. Chem. 57: $85-95$.

Brock, T. D., M. T. Madigan, J. M. Martinko, and J. Parker. 1994. Biology of microorganisms, 7th ed. Prentice Hall.

Dauwe, B., And J. J. Middelburg. 1998. Amino acids and hexosamines as indicators of organic matter degradation state in North Sea sediments. Limnol. Oceanogr. 43: 782-798.

FuHRMAN, J. 2000. Impact of viruses on bacterial processes, p. 327350. In D. L. Kirchman [ed.], Microbial ecology of the oceans. Wiley.

Fukuda, R., H. Ogawa, T. Nagata, And I. Koike. 1998. Direct determination of carbon and nitrogen contents of natural bacterial assemblages in marine environments. Appl. Environ. Microbiol. 64: 3352-3358.

Giovannoni, S., AND M. RAPpÉ. 2000. Evolution, diversity, and molecular ecology of marine prokaryotes, p. 47-84. In D. L. Kirchman [ed.], Microbal ecology of the oceans. Wiley.

Hung, C.-C., D. Tang, K. W. WarnKen, And P. H. SAntschi. 2001. Distributions of carbohydrates, including uronic acids, in estuarine waters of Galveston Bay. Mar. Chem. 73: 305318.

Ittekot, V., W. G. Deuser, And E. T. Degens. 1984. Seasonality in the fluxes of sugars, amino acids, and amino sugars to the deep ocean: Sargasso Sea. Deep-Sea Res. 31: 1057-1069.

KAISER, K., AND R. BENNER. 2000. Determination of amino sugars in environmental samples with high salt content by high-performance anion-exchange chromatography and pulsed amperometric detection. Anal. Chem. 72: 2566-2572.

Karner, M. B., E. F. DeLong, And D. M. KarL. 2001. Archaeal dominance in the mesopelagic zone of the Pacific Ocean. Nature 409: 507-510.

Kirchman, D. L., And J. White. 1999. Hydrolysis and mineralization of chitin in the Delaware estuary. Aquat. Microb. Ecol. 18: $187-196$.

- B. Meon, H. W. Ducklow, C. A. Carlson, D. A. HanSELL, AND G. F. STEWARD. 2001. Glucose fluxes and concentrations of dissolved combined neutral sugars (polysaccharides) in Ross Sea and Polar Front Zone, Antarctica. Deep-Sea Res. II 48: 4179-4197.

Koike, I., S. Hara, K. Terauchi, and K. Kogure. 1990. Role of sub-micrometer particles in the ocean. Nature 345: 242-244.

LiebezeIt, G. 1993. Amino sugars in Bransfield Strait and Weddell Sea sediments. Senckenb. Marit. 23: 29-35.

McCarthy, M., J. I. Hedges, And R. Benner. 1996. Major biochemical composition of dissolved high molecular weight organic matter in seawater. Mar. Chem. 55: 281-298.

, T. Pratum, J. I. Hedges, and R. Benner. 1997. Chemical composition of dissolved organic nitrogen in the ocean. Nature 390: $150-154$.

- J. I. HedGes, ANd R. BenNer. 1998. Major bacterial contribution to marine dissolved organic nitrogen. Science 281: 231-234.

Mclachlan, J., A. G. McInnes, And M. Falk. 1965. Studies on the chitan (chitin: poly- $N$-acetyl-glucosamine) fibers of the diatom Thalassiosira fluviatilis Hustedt. Production and isolation of chitan fibers. Can. J. Bot. 43: 707-713.

Meon, B., And D. L. Kirchman. 2001. Dynamics and molecular composition of dissolved organic material during experimental phytoplankton blooms. Mar. Chem. 75: 185-199.

MimuRA, T., AND J.-C. Romano. 1985. Muramic acid measurements for bacterial investigations in marine environments by highpressure liquid chromatography. Appl. Environ. Microbiol. 50: 229-237.

Mopper, K., J. Zhou, K. S. Ramana, U. Passow, H. G. Dam, and D. T. DRAPEAU. 1995. The role of surface-active carbohydrates in the flocculation of a diatom bloom in a mesocosm. DeepSea Res. 42: 47-73.

Moriarty, D. J. W. 1977. Improved method using muramic acid to estimate biomass of bacteria in sediments. Oecologia 26: 317-323.

, AND A. C. HAYWARD. 1982. Ultrastructure of bacteria and the proportion of Gram-negative bacteria in marine sediments. Microb. Ecol. 8: 1-14.

Müller, P. J., E. Suess, ANd C. A. Ungerer. 1986. Amino acids and amino sugars of surface particulate and sediment trap material from waters of the Scotia Sea. Deep-Sea Res. 33: 819838.

Muzzarelli, R. A. A. 1977. Chitin. Pergamon.

Nagata, T. 2000. Production mechanisms of dissolved organic matter, p. 121-152. In D. L. Kirchman [ed.], Microbial ecology of the oceans. Wiley.

Obernosterer, I., B. Reitner, ANd G. J. Herndl. 1999. Contrasting effects of solar radiation on dissolved organic matter and its bioavailability to marine bacterioplankton. Limnol. Oceanogr. 44: 1645-1654.

Ogawa, H., Y. Amagai, I. Koike, K. Kaiser, and R. Benner. 2001. Production of refractory dissolved organic matter by bacteria. Science 292: 917-920.

PAKUlSKI, J. D., AND R. BENNER. 1994. Abundance and distribution of dissolved carbohydrates in the ocean. Limnol. Oceanogr. 39: 930-940.

RomanKeVICH, E. A. 1984. Geochemistry of organic matter in the ocean. Springer.

SCHLEIFER, K. H., AND O. Kandler. 1972. Peptidoglycan types of bacterial cell walls and their taxonomic implications. Bacteriol. Rev. 36: 407-477.

Sharon, N. 1965. Microorganisms, plants, and invertebrates, p. 145. In E. A. Balazs and R. W. Jeanloz [eds.], The amino sugars: the chemistry and biology of compounds containing amino sugars. Academic.

SKoOG, A., AND R. BENNER. 1997. Aldoses in various size fractions of marine organic matter: Implications for carbon cycling. Limnol. Oceanogr. 42: 1803-1813. 
STROM, S. L. 2000. Bacterivory: Interactions between bacteria and their grazers, p. 351-386. In D. L. Kirchman [ed.], Microbial ecology of the oceans. Wiley.

TAnoue, E., S. Nishiyama, M. Kamo, And A. Tsugita. 1995. Bacterial membranes: Possible source of a major dissolved protein in seawater. Geochim. Cosmochim. Acta 59: 2643-2648.

Wakeham, S. G., T. K. Pease, And R. Benner. In press. Hydroxy fatty acids in marine dissolved organic matter as indicators of bacterial membrane material. Org. Geochem.

Wells, M. L., AND E. D. GoldBerG. 1991. Occurrence of small colloids in seawater. Nature 353: 342-344.

Received: 15 March 2002

Accepted: 21 August 2002

Amended: 17 September 2002 